\title{
"Evolved Materials and Innovative Design for High Performance, Durable and Reliable SOFC Cell and Stack" Presentation and Status of the European Project EVOLVE
}

\author{
R. Costa and A. Ansar \\ German Aerospace Center, Institute of Technical Thermodynamics, Electrochemical \\ Energy Technology, Pfaffenwaldring 38-40, 70569 Stuttgart, Germany
}

Beyond the state of the art, EVOLVE aims at the development of a new cell architecture for SOFC, combining benefits of existing Anode Supported (high power density, lifetime) and Metal Supported cell (redox stability) architectures, while limiting the issue of sulphur poisoning by using enhanced perovskite anode materials. The core component is based on a composite anode substrate made of porous Alumina forming alloy combined with an electron conducting oxide ceramic, without having Nickel as structural component. A first Anode/Electrolyte assembly based on a $\mathrm{NiCrAl}$ foam and $\mathrm{La}_{0,1} \mathrm{Sr}_{0,9} \mathrm{TiO}_{3-\alpha}$ has been produced by means of Vacuum Plasma Spraying, showing the feasibility of this cell concept. With a requirement of a low temperature process, the manufacturing of the electrolyte layer remains the key challenge. Work is under progress for the manufacturing and testing of the first full prototype.

\section{Introduction}

Emission of greenhouse gases (GHG) from industry, transportation and agriculture has played a major role in the recently observed global warming. In order to reduce the impact on environment, zero or near-zero emission energy systems, converting fuel efficiently into useful energy are increasingly investigated. Unprecedented rise in the fossil fuel prices has led to a growing economic concern towards the need of such energy systems. Additionally, geopolitical priority of reducing the dependence on foreign energy resources emphasizes the development of systems that may work with a variety of fuels and eventually with renewable energy resources such as hydrogen or bio-fuels.

Solid Oxide Fuel Cells (SOFCs) are one of the most attractive energy conversion devices, owing to the potential of operating at high efficiency of about $60 \%$ in standalone condition and over $80 \%$ (net) if waste heat is used for cogeneration. SOFCs do not require noble metals for catalysis in electrodes and may use a variety of fuels including hydrocarbons, $\mathrm{CO}$ and bio-fuels, besides hydrogen. These low-noise convertors thus offer very high potential in stationary application and combined heat and power units (CHP) for decentralized energy and in Auxiliary Power Units (APU) as well for mobile applications. Despite all the promising advantages and the unparalleled progress in its power output, SOFC faces critical challenges in term of its poor reliability, low durability and higher cost. Unless addressed meticulously, these obstacles will impede large-scale commercialization of fuel cells. Reliability and durability are adversely affected by a 
number of factors of which the following two can be considered as the route cause: 1) high operating temperatures $\left(800-1000^{\circ} \mathrm{C}\right)$ of SOFC and 2) the need to use materials that provide multiple functionalities. This includes structural support, electrochemical activity, and electrical or ionic conduction, as well as at the same time compatibility with neighboring components during the manufacturing process and fuel cell operation.

\section{$\underline{\text { State of the Art }}$}

Looking back to the cell architectures which have been investigated in the last decades, one can point out three main cell designs: the oldest one or the first cell generation is the so called Electrolyte Supported Cell (ESC). The second cell generation which can be named as Anode Supported Cell (ASC) and finally the third architecture, called the Metal Supported Cell (MSC) have been then successively developed, targeting for each of them improved performance and reliability in comparison to the former one.

$1^{\text {st }}$ Generation: Electrolyte Supported Cell (ESC). The cell is built over a thick electrolyte substrate made of yttria-stabilized-zirconia (YSZ) which provides the mechanical stability to the cell. Very robust in a mechanical point of view, one can nonetheless mention that the power density is limited by the thickness of the electrolyte layer, typically in the range $100-200 \mu \mathrm{m}$, which thus imply a high working temperature. A long starting time makes them not appropriate for transportation, where fast procedures are required.

$2^{\text {nd }}$ Generation: Anode Supported Cell (ASC). Such cells are usually based on a thick anode layer $(>300 \mu \mathrm{m})$ made of a nickel oxide and yttria-stabilized-zirconia (NiO/YSZ) composite exhibiting an electronic conductivity higher than $100 \mathrm{~S} \cdot \mathrm{cm}^{-1}$. On top of it, an active anode layer (NiO and YSZ), an electrolyte layer (YSZ) and then a suitable cathode, Lanthanum Strontium Manganite or more recently Lanthanum Strontium Cobalt Ferrite together with Gadolinia doped ceria diffusion barrier layer, are coated. This cell design has been widely developed in the last ten years and recent studies have shown unprecedented specific power output at cell and stack levels, thanks to the reduction of the electrolyte thickness. For example, Han et al (1) have reported $1092 \mathrm{~mW} / \mathrm{cm}^{2}$ at $650{ }^{\circ} \mathrm{C}$ using $\mathrm{H}_{2}, 6 \% \mathrm{H}_{2} \mathrm{O}$ and air as fuel and oxidizing gases. Similarly typical power output at a stack level of anode-supported cells produced by CERAMTEC AG, measured by the German Aerospace Center in the framework of ZeuSIII project (funded by BMWi, Germany), is about $500 \mathrm{~mW} / \mathrm{cm}^{2}$ at $750{ }^{\circ} \mathrm{C}$ at about $40 \%$ fuel utilization using a mixture $\mathrm{H}_{2} / \mathrm{N}_{2} / \mathrm{H}_{2} \mathrm{O}(48,5: 48,5: 3$ in volume) as fuel and air as oxidant (2). This makes the anodesupported cell design the most mature technology for market entry. However, despite all these promising results, this concept still has to face critical challenges to improve reliability, flexibility and life time. In fact, combined with the high operating temperatures, degradation mechanisms in cell are promoted including mainly $\mathrm{Ni}$ coarsening and agglomeration in the anode (3-5), diffusion of Ni into YSZ causing degradation of its ionic conductivity (6), and grain boundary or triple phase boundary segregation of non-active and isolating secondary phases such as $\mathrm{SiO}_{2}(7)$, present as internal impurity or coming from an external source, for instance due to evaporation from glass seals. DTU in Denmark has worked on this issue by using a gas cleaning system to avoid formation of secondary phases (8). Additional mechanisms of degradation may intervene due to inter-material reactivity, for example, between cathode and electrolyte at stack level due to poisoning of active layers by volatile species. The use of syngas as fuel, 
containing few ppm of $\mathrm{H}_{2} \mathrm{~S}(>10 \mathrm{ppm})$, leads to an increase of the anode polarisation resistance caused by the chemical adsorption of sulphur on nickel particles (9-10). This decreases the performance of the cell. For reduced operating temperatures, issues of coking and sulphur poisoning become pronounced. Furthermore, reliability of the anodesupported cells consisting of $\mathrm{Ni}$ and YSZ as anode, in an event of redox cycling, is a serious challenge to be addressed. These cells have shown the reoxidation of the metallic nickel during shut-down procedure or accidental air entry due to system malfunctioning (11). This reoxidation followed by a reduction process leads to structural modification of the anode resulting in nickel coarsening (12) and in the appearance of stresses in the cell, causing eventually cracks and cell failure (9). Though some progress has been achieved in this respect (13), the reliability of auxiliary power units based on nickel-containing cermet anodes is still questionable.

$3^{\text {rd }}$ Generation: Metal Supported Cell (MSC). In order to overcome some of abovedescribed challenges associated with the anode-supported cell, metal-supported solid oxide fuel cells (MSC) have been developed which offer significant advantages in terms of excellent mechanical stability, robustness under transient conditions, rapid start-up and lower costs (14). Therefore, several research and industrial teams are working with this concept. Takenoiri et al. (15) presented a Ni-felt substrate supported cell with anode and electrolyte layers formed by flame spraying and atmospheric plasma spraying, respectively. A $3 \mathrm{~kW}$-class stack consisting of bilayer electrolytes of $\mathrm{Y}_{2} \mathrm{O}_{3}$-stabilized $\mathrm{ZrO}_{2}$ (YSZ) and $\mathrm{Y}_{2} \mathrm{O}_{3}$-doped $\mathrm{CeO}_{2}$ (YDC) was constructed to generate $3.3 \mathrm{~kW}$ at $970{ }^{\circ} \mathrm{C}$ at $300 \mathrm{mAcm}^{-2}$. Villarreal et al. (16) reported that porous ferritic steel-supported cells fabricated by colloidal spray processing and powder metallurgy using 70/30 $\mathrm{Fe} / \mathrm{Cr}$ Ametek alloy powder exhibited maximum power densities of 100 and $200 \mathrm{mWcm}^{-2}$ at 800 and $900{ }^{\circ} \mathrm{C}$, respectively. Steele (17) has shown that single cells incorporating thin Gd-doped ceria electrolyte may produce a highly encouraging power density of 400 $\mathrm{mWcm}^{-2}$ at $500{ }^{\circ} \mathrm{C}$ on $\mathrm{H}_{2} \mathrm{O} / \mathrm{CH}_{4}(1: 1)$. Therefore, Ceres Power has demonstrated planar type low-temperature metal-supported SOFCs fabricated based on 10-30 $\mu \mathrm{m}$ electrolytes of $\mathrm{Gd}$-doped ceria and perforated Ti-Nb-stabilized $17 \% \mathrm{Cr}$ ferritic stainless-steel $(14,18)$. Maximum power densities of $310 \mathrm{mWcm}^{-2}$ and $240 \mathrm{mWcm}^{-2}$ were obtained at 600 and $550{ }^{\circ} \mathrm{C}$ under moist hydrogen/air. The electrolyte was deposited using an electrophoretic deposition process and the electrodes were deposited by wet spraying or screen-printing. Yoo et al. (19) have developed planar type MSC by using RF magnetron sputtering and pulse injection type wet colloidal spray, demonstrating maximum power densities of 370 $\mathrm{mWcm}^{-2}$ at $600{ }^{\circ} \mathrm{C}$ from single cells of SSC // SDC/ScSZ // NiO+SDC on a ferritic steel substrate under humid $50 \% \mathrm{H}_{2}$ in $\mathrm{Ar}\left(3 \% \mathrm{H}_{2} \mathrm{O}\right)$ and air. Tucker et al. $(20,21)$ at Lawrence Berkeley National Laboratory manufactured tubular metal-supported cells by sintering, using a YSZ electrolyte and infiltrated electrodes exhibiting power densities of 332 $\mathrm{mWcm}^{-2}$ at $0.7 \mathrm{~V}$ while operating at $700^{\circ} \mathrm{C}$ with moist $\mathrm{H}_{2}$ /air. Hui et al. (22) employed suspension based plasma and $\mathrm{HVOF}$ spraying and screen printing to produce $\mathrm{SSC} / \mathrm{SCD} / / \mathrm{SDC}+\mathrm{NiO}$ functional layers on a Hastelloy substrate. Maximum power densities of 560 and $260 \mathrm{mWcm}^{-2}$ were reported at 700 and $600{ }^{\circ} \mathrm{C}$ respectively for $5 \times 5$ $\mathrm{cm}^{2}$ cells using moist $\mathrm{H}_{2}$ and air. Vaßen (23) and Kesler (24) are also developing metalsupported cells using different types of thermal spray techniques. The German Aerospace Center has been working on metal-supported cells by plasma spraying and has demonstrated cells of $12.56 \mathrm{~cm}^{2}$ surface area exhibiting $609 \mathrm{~mW} / \mathrm{cm}^{2}$ at $0.7 \mathrm{~V}$ with $\mathrm{H}_{2} /$ air whereas $85 \mathrm{~cm}^{2}$ single cell in stack configuration and a 10 cell stack had respectively 384 and $306 \mathrm{~mW} / \mathrm{cm}^{2}$ power densities at $40 \%$ fuel utilization (25). Good cyclability could be 
validated as 20 full-redox and 20 thermal cycles led to $14 \%$ degradation in power density. However, the power density remained mediocre compared to anode-supported cells and due to degradation of metal support and inter-diffusion between species of anode and metal substrate, non-cyclic degradation rate of MSC was measured to be as high as $8.5 \% / \mathrm{kh}$ (25). If this cell architecture present clear benefits for mobile application, their limited lifetime make questionable their potential use in stationary applications.

Nickel Less Anode Materials. Beside the development done on the cell design itself, the achievements from the last years pointed out some critical aspects due to the use of Nickel, either on a mechanical point of view, because of the volume change appearing during a redox cycle, causing failure of ASC or degradation of MSC, or because of its high sensitivity towards sulfur poisoning in both of these architecture. Therefore During the last ten years, researchers have been active worldwide to develop nickel-free anode materials for SOFCs (26). Ceramics exhibiting both ionic and electronic conductivity (MIEC) in a reducing environment have received a strong interest, and it has been highlighted that perovskite structures are less reactive with $\mathrm{H}_{2} \mathrm{~S}$ than the nickel-based anode (27). $\mathrm{SrTiO}_{3}$ and $\mathrm{La}_{0,75} \mathrm{Sr}_{0,25} \mathrm{Cr}_{0,5} \mathrm{Mn}_{0,5} \mathrm{O}_{3-\alpha}$ (LSCM) have been investigated in the field of the European projects REAL SOFC and SOFC 600, and are considered as the most promising MIEC for anode applications in SOFCs (28-32). According to recent publications it is possible to obtain anodes based on La-doped $\mathrm{SrTiO}_{3}$ and impregnated with a nickel catalyst exhibiting an ASR around $0.21 \Omega \cdot \mathrm{cm}^{2}$ at $700{ }^{\circ} \mathrm{C}$ in pure $\mathrm{H}_{2} / \mathrm{O}_{2}(13)$. However, most of these compounds exhibit an electronic conductivity of only around 1 $\mathrm{S} \cdot \mathrm{cm}^{-1}$ in the operating range of temperature of SOFCs (11-12). This makes them difficult to be used as current collector for anode-supported fuel cells even if the porous backbone is impregnated with a metal like copper (13). As an alternative, in Canada, Fu et al. (33) proposed the use of copper-coated nickel foam as current collector for an SOFC with LSCM anode operated on syngas as fuel. However, even if the use of LSCM reduces drastically the degradation due to sulphur poisoning, the use of a nickel-based current collector does not solve the degradation correlated with redox cycling.

Beyond the state of the art, the EVOLVE cell concept will assist in combining the beneficial characteristics of the previous cell generations, the so called ASC and MSC and will address further key challenge like sulfur poisoning, of these two competing technologies by the use of advanced anode materials.

\section{EVOLVE: Cell Concept and Presentation}

The cell, represented schematically in Figure 1, will consist of functional layers supported on an innovative anode current collector which constitutes the core component of the EVOLVE concept.

This current collector is based on a ceramic metal composite in form of metallic foams, impregnated with an electronic conductive ceramic, without having Nickel percolating networks. Because percolation of nickel is not necessary for the current collection the nuisance of $\mathrm{Ni}$ coalescence and redox failure in state-of-the-art cells will be avoided. 


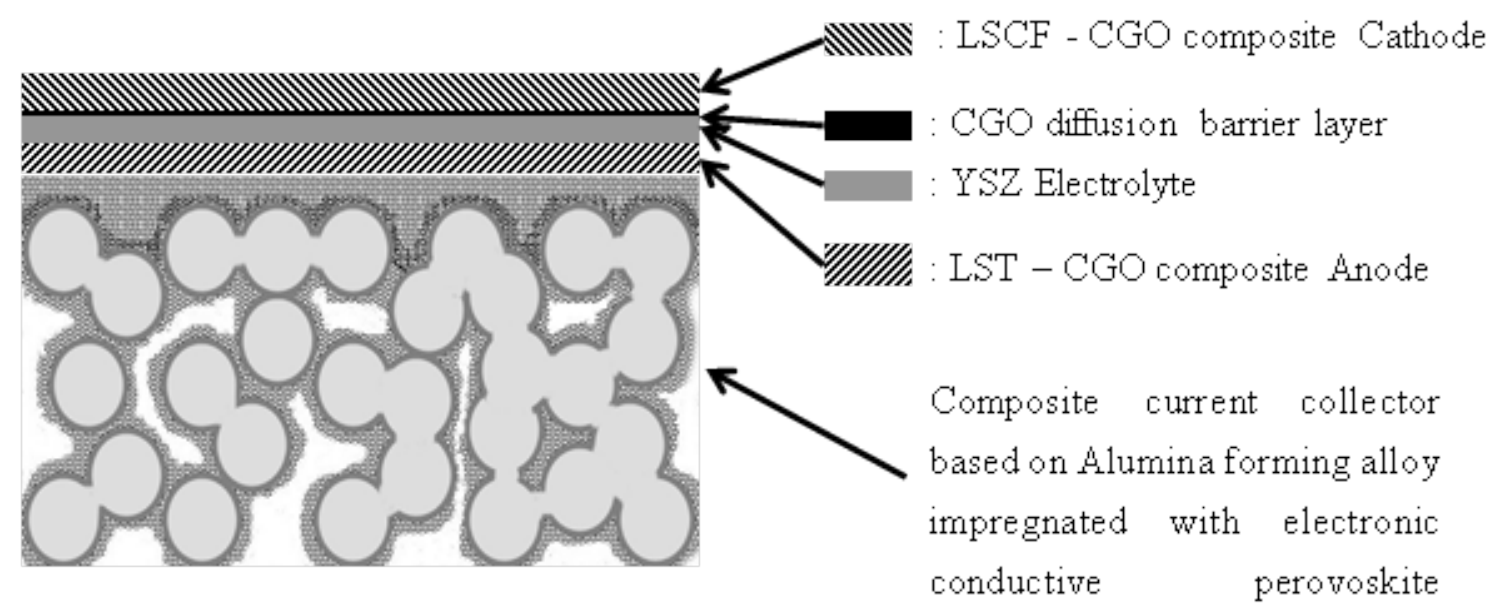

Figure 1. Schematic of the EVOLVE cell architecture.

The metallic foam is made of an alloy composition that allows the formation of a thin continuous stable oxide layer of $\mathrm{Al}_{2} \mathrm{O}_{3}$. The main advantage of this oxide is in its thermal stability and its ability to slow down the oxidation kinetics of the underlying metal in case of exposure to oxidant environment. $\mathrm{Al}_{2} \mathrm{O}_{3}$-forming alloys are therefore significantly more durable compared to the $\mathrm{Cr}$-forming alloys at elevated temperatures which are commonly used in the MSCs. The backbone of metal foam is impregnated with conductive ceramics such as LSCM $\left(\mathrm{La}_{(1-x)} \mathrm{Sr}_{x} \mathrm{Cr}_{(1-y)} \mathrm{Mn}_{y} \mathrm{O}_{3-\alpha}\right)$ or LST $\left(\mathrm{La}_{(1-x)} \mathrm{Sr}_{x} \mathrm{TiO}_{3-x}\right)$, which lead to a percolating phase of electron conductor and acting as well as a further protective layer toward oxidation. This composite current collector will provide a robust structural integrity of the cell as for MSCs whereas thin alumina scale will enhance its chemical stability under cell fabrication and operating conditions. Thanks to its robustness, thin active layers, and especially thin electrolyte can be manufactured, which theoretically allows to reach power density comparable to the one achieved with ASC thanks to limited ohmic losses. Therefore, major improvements in term of redox stability and resistance toward sulfur poisoning is expected and one expect, in optimal condition, a flexible durable and reliable cell able to operate either for stationary use or for transportation

This concept is at the origin of the project EVOLVE, which received funding from the European Union's Seventh Framework Programme (FP7/2007-2013) for the Fuel Cells and Hydrogen Joint Technology Initiative under grant agreement $n^{\circ} 303429$. The consortium, coordinated by the German Aerospace Center, is composed of a total of eight European research institutes and companies. These partners are: German Aerospace Center (Germany) for the coordination and mainly for the development of the current collector, the active layers, the up-scaling and stack testing, Alantum Europe $\mathrm{GmbH}$ (Germany) for the development of the metal foam, ARMINES (France) for advanced microstructural characterization and modeling, CerPoTech AS (Norway) for the development and the manufacturing of anode materials, CNR (Italy) for the development of materials and the shaping of active layers, Grenoble INP (France) for electrochemical characterization, Ceraco GmbH (Germany) for the development of thin PVD layers, and Saan Energi AB (Sweden) for the up-scaling and the bench marking activities. This project has started in November 2012 for a whole duration of 4 years, with the 
development of the cell, its up-scaling at an industrially relevant size, and its integration in a mature pre-industrial stack as final goals.

\section{Technical Status in May 2013}

The activity of these first 7 months was focused on the technical feasibility of the EVOLVE cell concept and on the manufacturing of anode/electrolyte assembly which is presented here after.

\section{Selection of Materials and Manufacturing.}

For this feasibility study, $\mathrm{La}_{0,1} \mathrm{Sr}_{0,9} \mathrm{TiO}_{3-\alpha}$ (LST10) provided by Cerpotech AS (Norway) have been selected and developed as reference perovskite material for both the current collector and the active anode layer. $\mathrm{Ce}_{1,9} \mathrm{Gd}_{0,1} \mathrm{O}_{2-\alpha}$ (CGO10) from Treibacher Industrie AG (Austria) with comparable particle size distribution have been used for the development of composite anode materials. Both powders were mixed together in a ratio 50:50 in weight to prepare ethanol based slurries for the purpose current collector manufacturing and active functional anode layer.

A NiCrAl standard foam ( $\mathrm{NiCrAl} \mathrm{\# 1)} \mathrm{from} \mathrm{Alantum} \mathrm{Europe} \mathrm{GmbH}$, with an open cell size of about $450 \mu \mathrm{m}$ has been used as Alumina forming alloy, under a form of sheets with $1,6 \mathrm{~mm}$ in thickness. Samples with $50 \mathrm{~mm}$ x $50 \mathrm{~mm}$ were cut from these sheets. These metal substrates were first impregnated with the developed slurry, before being pressed and laminated with the anode tape with the same solid composition, the total thickness of the current collector being less $700 \mu \mathrm{m}$. After firing in air at $1000^{\circ} \mathrm{C}, \mathrm{YSZ}$ electrolyte was deposited by means of Vacuum Plasma Spraying, in order to avoid the exposure of the metal foam to high temperature, typically $1400^{\circ} \mathrm{C}$, which is commonly used for the manufacturing of gas tight dense electrolyte by the sintering approach.

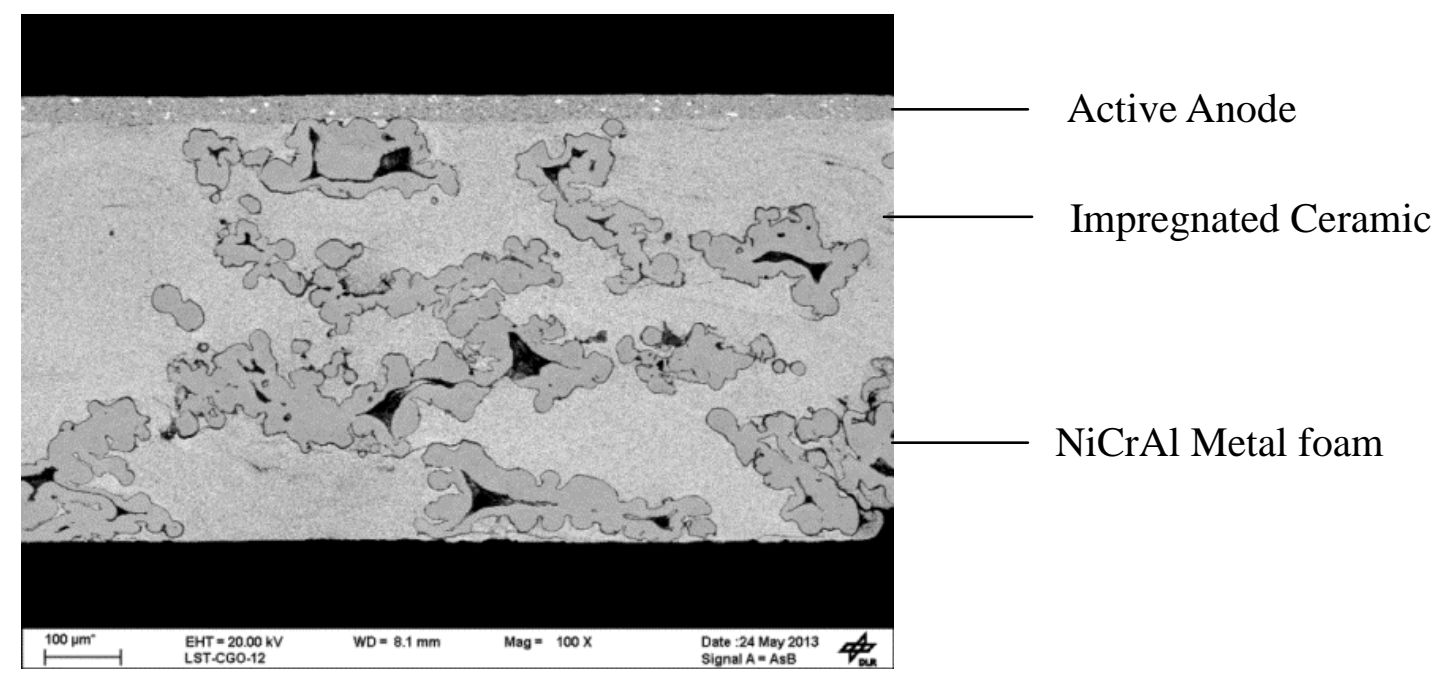

Figure 2. BSE SEM polished cross section of a EVOLVE type current collector after firing in air. 


\section{Results and Discussions.}

The figure 2 shows the microstructure of EVOLVE type current collector. After firing, a smooth crack free current collector able to support the next active layers has been obtained.

After plasma spraying, it was possible to cover the current collector with a continuous YSZ layer (Figure 3). In a technical point of view, this demonstrates the technical feasibility of such architecture and assembly. One should however notice that the active anode layer was fully removed during the thermal spraying process. This can be explained by the high speed of impact of the molten YSZ particles on the top surface of the anode. However, keeping in mind that the impregnated ceramic within the foam was from the same composition than the active anode layer, one should expect similar catalytic performance. But the strengthening and the microstructural optimization of the active anode layer remains a topic for further development.

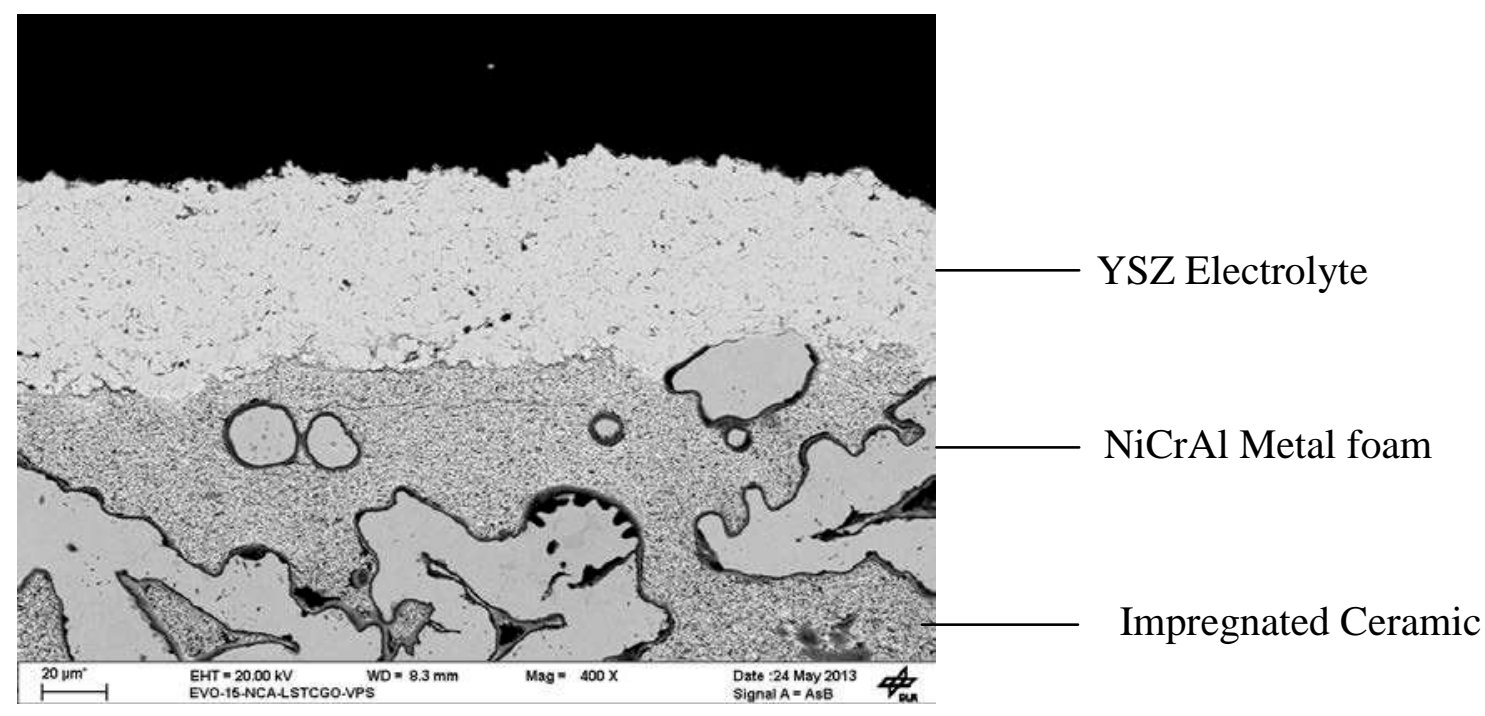

Figure 3. BSE SEM polished cross section of a EVOLVE anode/electrolyte assembly after the deposition of YSZ electrolyte by means of Vacuum Plasma Spraying.

The manufacturing of a gas tight dense and thin Electrolyte layer over an anodic substrate consisting in the current collector itself with the active anode layer with fully optimized composition and microstructure, is actually the key challenge of the concept, knowing that high temperature processes $\left(>1200^{\circ} \mathrm{C}\right)$ like sintering, must be avoided to keep the integrity of the metal foam and to maintain its mechanical property for the purpose of mechanical stability and current collection. Fast thermal process like Plasma Spraying, or low temperature coating processes like PVD are currently under consideration for the manufacturing of the electrolyte layer.

At this stage of the project (May 2013), the focus is actually on the evaluation of the capability of the substrate in term of current collection, the finalization of the first cell prototype, and the electrochemical characterization of the first EVOLVE type cell. 


\section{Conclusion}

Beyond the existing cell design, a new cell concept based on innovative composite current collector without having nickel as structural component has been presented. This composite current collector, made of an alumina forming alloy together with a perovskite based electronic conductor is expected when combined with a perovskite based anode material to bring improved characteristics performance compared with both ASC and MSC technology, especially when redox cyclability and sulfur tolerance are considered. In the frame of the European project EVOLVE, a first anode/electrolyte assembly based on this composite current collector, has been manufactured using a NiCrAl foam as metallic substrate and LST10 as perovskite materials. This showed the feasibility of such cell architecture. One of the key challenge of the development of such cell remains in the manufacturing of a gas tight electrolyte avoiding high temperature processes. Work is actually running on the evaluation of properties of the current collector, manufacturing and testing of a full cell prototype and additional results are expected in the next coming months.

\section{Acknowledgments}

All the coworkers from the German Aerospace Center (Germany), Alantum Europe GmbH (Germany), ARMINES (France), CerPoTech AS (Norway), CNR (Italy), Grenoble INP (France), Ceraco GmbH (Germany), and Saan Energi AB (Sweden) who have been involved in the framework of the project EVOLVE are gratefully acknowledged for their contribution to this work.

The project has received funding from the European Union's Seventh Framework Programme (FP7/2007-2013) for the Fuel Cells and Hydrogen Joint Technology Initiative under grant agreement $\mathrm{n}^{\circ} 303429$.

\section{References}

1. F. Han, A. Leonide, T. van Gestel, H. P. Buchkremer, proceeding of the $10^{\text {th }}$ European Fuel Cell Forum, Luzern, Switzerland (2010).

2. M. Lang, C. Westner, R. Geieregger, B. Bentlohner, R. Schwub, proceeding of the $10^{\text {th }}$ European Fuel Cell Forum, Luzern, Switzerland (2010).

3. P. Lohsoontorn, D.J.L. Brett, N.P. Brandon, J. Power Sources 183, 232 (2008).

4. D.G. Ivey, E. Brightman, N. Brandon, J. Power Sources 195, 6301 (2010).

5. L. Holzer, B. Iwanschitz, Th. Hocker, B. Münch, M. Prestat, D. Wiedenmann, U. Vogt, P. Holtappels, J. Sfeir, A. Mai, Th. Graule, J. Power sources 196, 1279 (2011).

6. W.G. Coors, J.R. O'Brien, J.T. White, Solid State Ionics, 180, 246 (2009).

7. Y.L.Liu, S. Primdahl, M. Mogensen, Solid State Ionics, 161, 1 (2003).

8. SD Ebbesen, M. Mogensen, Electrochem. Solid-State Let., 13, B106 (2010).

9. J.P. Trembly, A.I. Marquez, T.R. Ohrn, D. J. Bayless, J. Power Sources, 158, 263 (2006).

10. J.F.B. Rasmussen, A. Hagen, J. Power Sources, 191, 534 (2009). 
11. M. Ettler, H. Timmermann, J. Malzbender, A. Weber, N.H. Menzler, J. Power Sources, 195, 5452 (2010).

12. T. Klemenso, M. Mogensen, Journal of. Am. Ceram. Soc., 90, 3582 (2007).

13. Q. Ma, F.Tietz, A. Leonide, E. Ivers-Tiffée, Electrochem. Commun., 12, 1326 (2010).

14. P. Bance, N.P. Brandon, B. Girvan, P. Holbeche, S. O’Dea, B.C.H. Steele, J. Power Sources, 131, 86 (2004).

15. S. Takenoiri, N. Kadokawa, K. Koseki, J. Thermal Spray Tech., 9, 360 (2000).

16. I. Villarreal, C. Jacobson, A. Leming, Y. Matus, S. Visco, L. DeJonghe, Electrochem. Solid-State Let., 6, 178 (2003).

17. B.C.H. Steele, Solid State Ionics, 129, 95 (2000).

18. R.T. Leah, N.P. Brandon, P. Aguiar, J. Power Sources, 145, 336 (2005).

19. Y. Yoo, N. Oishi, D. Roth, S. Nikumb, 4th SOFC international conference proceeding in 31st Cocoa beach conference, Daytona Beach, FL, USA, Jan. 2126, (2007).

20. M.C. Tucker, G.Y. Lau, C.P. Jacobson, L.C. DeJonghe S.J. Visco, J. Power Sources, 175, 447 (2008).

21. M.C. Tucker, G.Y. Lau, C.P. Jacobson, L.C. DeJonghe, S.J. Visco, J. Power Sources, 171, 477 (2007).

22. R. Hui, J.O. Berghaus, C Decès-Petit, W. Qu, S. Yick, J.G. Legoux, C. Moreau, J. Power Sources, 191, 371 (2009).

23. R. Vaßen, D. Hathiramani, J. Mertens, V.A.C. Haanappel, I.C. Vinke, Surface Coating Tech., 202, 371 (2007).

24. D. Waldbillig, O. Kesler, J. Power Sources, 191, 320 (2009).

25. P. Szabo, J. Arnold, T. Franco, M. Gindrat, A. Refke, A. Zagst, A. Ansar, ECS Trans., 25, 175 (2009).

26. M.Gong, X. Liu, J. Trembly, C. Johnson, J. Power Sources, 168, 289 (2007).

27. R. Munkundan, E. L. Brosha, H.H. Garzon, Electrochem. Solid State Let., 7, A5 (2004).

28. E. Lay, G. Gauthier, S. Rosini, C. Savaniu, J.T.S. Irvine, Solid State Ionics, 179, 1562 (2008).

29. P. Blennow, A. Hagen, K.K. Hansen, L.Reine Wallenberg, M. Mogensen, Solid State Ionics, 179, 2047 (2008).

30. C.-D. Savaniu, J,T,S, Irvine, J. Mat. Chem., 19, 8119 (2009).

31. C.-D. Savaniu, J.T.S. Irvine, Solid State Ionics, 192, 491 (2011).

32. B.H. Smith, W. C. Holler, M. D. Gross, Solid State Ionics 192, 383 (2011).

33. X.-Z. fu, J. Melnik, Q.-X. Low, J.-L.Luo, K.T. Chuang, A.R. Sanger, Q.-M. Yang, Int. J. Hydrogen Energy, 35, 11180 (2010). 